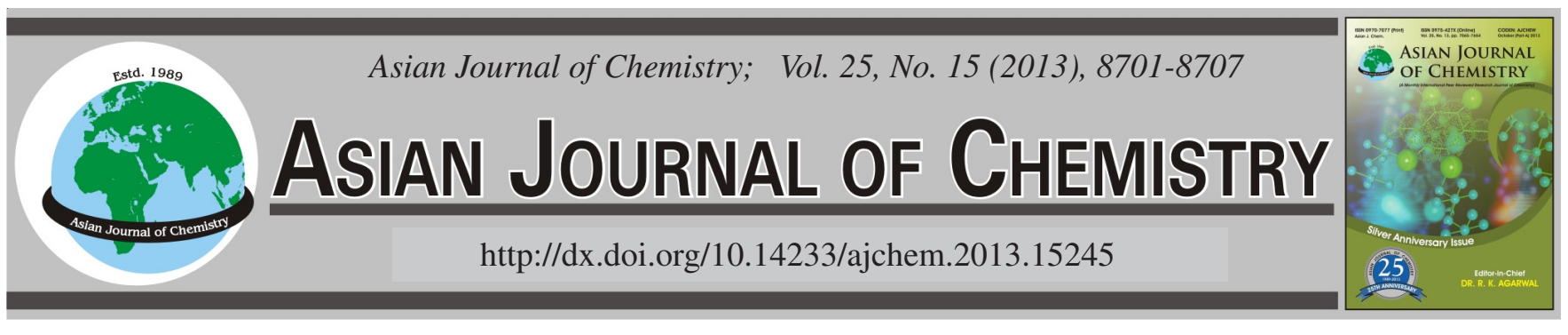

\title{
A Novel Synthesis of (4aS,7aS)-Octahydro-1H-pyrrolo[3,4-b]pyridine: An Intermediate of Moxifloxacin Hydrochloride
}

\author{
G. Prashanth REDDY ${ }^{1,2}$ and RaKeShWAR BANDichHOR ${ }^{1, *}$
}

${ }^{1}$ API R\&D, Integrated Product Development, Innovation Plaza, Dr. Reddy's Laboratories Ltd, Bachupally, Qutubullapur, Hyderabad-500 072 , India ${ }^{2}$ Center for Environment, Institute of Science and Technology, Jawaharlal Nehru Technological University, Kukatpally, Hyderabad-500 072, India

*Corresponding author: Fax: +91 40 446285; Tel: +91 40 44346117; E-mail: rakeshwarb@drreddys.com

(Received: 31 January 2013;

Accepted: 26 August 2013)

AJC-14030

A novel synthesis of (4aS, $7 \mathrm{aS}$ )-octahydro- $1 H$-pyrrolo[3,4-b]pyridine (1) is demonstrated alongwith recovery and reuse of chiral auxiliary naproxen. Further to this alternative stereoselective reduction procedures on 6-benzyl-5H-pyrrolo[3,4-b]pyridine-5,7(6H)-dione 3 enabling the desired chirality in the nonane $\mathbf{1}$ is demonstrated.

Key Words: Nonane, Racemization, Naproxen, Naproxamide, L-Proline.

\section{INTRODUCTION}

(4aS,7aS)-Octahydro-1H-pyrrolo[3,4-b]pyridine $\mathbf{1}$, is an important intermediate in the manufacture of moxifloxacin and commonly known as "nonane". For the past few decades, enormous amount of research has been carried out and several processes are reported $^{1-8}$.

Literature $^{1-8}$ illustrated that the majority of manufacturers follow the resolution process (Scheme-I), which involves coupling of 2,3-pyridine dicarboxylic acid $\mathbf{2}$ with benzylamine to obtain 3 followed by pyridine ring reduction to afford intermediate $\mathbf{4}$ which upon reduction of carbonyl groups afforded N-benzyl nonane intermediate 5. There after intermediate $\mathbf{5}$ was subjected to resolution with D-(-) tartaric acid in ethanol followed by deprotection to afford nonane $\mathbf{1}$.

Herein, we report alternative stereoselective reduction procedures on dione $\mathbf{3}$ as a source of chirality in the nonane $\mathbf{1}$.

\section{EXPERIMENTAL}

General: Solvents and reagents were used for all the reactions as received. The ${ }^{1} \mathrm{H}$ and ${ }^{13} \mathrm{C}$ NMR spectra were recorded in $\mathrm{CDCl}_{3} / \mathrm{DMSO}-d_{6}$ on Varian Gemini $400 \mathrm{MHz}$ or $500 \mathrm{MHz}$ FT NMR spectrometer; the chemical shifts were reported in $\delta$ ppm relative to tetramethylsilane TMS $(0 \mathrm{ppm})$. The FT-IR spectra were recorded in the solid state $\mathrm{KBr} /$ neat dispersion using Shimadzu IR Prestige-21 spectrophotometer. The mass spectra were recorded on SSMS PESCIEX, API-3000 machine in electron spray mode. The melting points were determined by using Polmon (Model No.: MP96) melting point apparatus. The specific optical rotation was recorded on Jasco P-2000 polarimeter and at $589 \mathrm{~nm}$. The chiral HPLC was recorded on Agilent Model 1260 by using Chiral AGP, $150 \times 4.0 \mathrm{~mm}$, $5 \mu$.

6-Benzyltetrahydro-1H-pyrrolo[3,4-b]pyridine$\mathbf{5 , 7}(\mathbf{6 H}, \mathbf{7 a} \boldsymbol{H})$-dione (4): $50 \mathrm{~g},(0.21 \mathrm{~mol}, 1.0 \mathrm{eq})$ of 6-benzyl$5 H$-pyrrolo[3,4-b]pyridine-5,7(6H)-dione 3 was added to 250 $\mathrm{mL}$ of toluene in hydrogen vessel, $29 \mathrm{~g},(0.252,1.2 \mathrm{eq})$ of L-proline was added and continued the stirring for $10 \mathrm{~min}$, $3.5 \mathrm{~g},(7 \%)$ of palladium charcoal on carbon was added. Stirring was continued for $15-30 \mathrm{~min}$ and warmed to $70{ }^{\circ} \mathrm{C}$ with $7-8 \mathrm{~kg} / \mathrm{cm}^{2}$ hydrogen pressure for $5-6 \mathrm{~h}$ and further warmed the reaction mass to $80-85^{\circ} \mathrm{C}$ with $8 \mathrm{~kg} / \mathrm{cm}^{2}$ hydrogen pressure for $9-10 \mathrm{~h}$, after completion of the reaction cooled to room temperature and catalyst was separated and washed with $100 \mathrm{~mL}$ of toluene. The clear filtrate was concentrated under reduced pressure at below $70{ }^{\circ} \mathrm{C}$ to furnish $49.5 \mathrm{~g}$, ( $0.20 \mathrm{~mol}$, $97.05 \%)$ of 6-benzyltetrahydro- $1 H$-pyrrolo[3,4-b]pyridine$5,7(6 \mathrm{H}, 7 \mathrm{aH})$-dione 4 with $15 \%$ ee. IR $\left(\mathrm{KBr}, \mathrm{v}_{\max }, \mathrm{cm}^{-1}\right)$ : $3382.49(\mathrm{NH}), 3034.40$ (aromatic $\mathrm{CH}), 2957.04$ (aliphatic $\mathrm{CH}$ ), $1718.93(\mathrm{C}=\mathrm{O}) ;{ }^{1} \mathrm{H}$ NMR (400 MHz, DMSO- $\left.d_{6}\right): \delta$ (ppm).7.25-7.34 (m, 5H), $4.56(\mathrm{~s}, 2 \mathrm{H}), 4.00(\mathrm{~d}, 1 \mathrm{H}, J=6.8$ $\mathrm{Hz}), 2.99$ (q, 1H, $J=6.4 \mathrm{~Hz}), 2.57-2.70(\mathrm{~m}, 2 \mathrm{H}), 1.77-1.84$ (m, 1H), 1.63-1.69 (m, 1H), 1.42-1.48 (m, 1H), 1.30-1.36 (m, $1 \mathrm{H}) ;{ }^{13} \mathrm{C}$ NMR (400 MHz, DMSO- $\left.d_{6}\right): \delta(\mathrm{ppm}) 178.20,177.09$, 136.25, 128.52, 127.39, 127.30, 72.16, 54.47, 41.73, 41.15, 40.12, 21.67; MS (ESI): $\mathrm{m} / \mathrm{z}$ calculated for $\mathrm{C}_{14} \mathrm{H}_{16} \mathrm{~N}_{2} \mathrm{O}_{2}(\mathrm{M}+\mathrm{H})$ : 244.2; found: $\left(\mathrm{M}+\mathrm{H}^{+}\right) 245.5$.

2,3-Bis(chloromethyl)pyridine (7): $25 \mathrm{~g}$, (0.142 mol, 1 eq) of pyridine-2,3-diyldimethanol hydrochloride was dissolved in $51.3 \mathrm{~g},(0.431 \mathrm{~mol}, 2.4 \mathrm{eq})$ of thionyl chloride 
<smiles>Cc1ccc2c(n1)C(=O)N(Cc1ccccc1)C2=O</smiles>

2<smiles>O=C1[C@H]2NCCC[C@H]2C(=O)N1Cc1ccccc1</smiles>

4

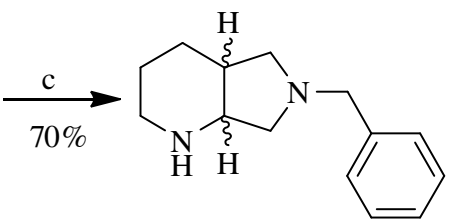

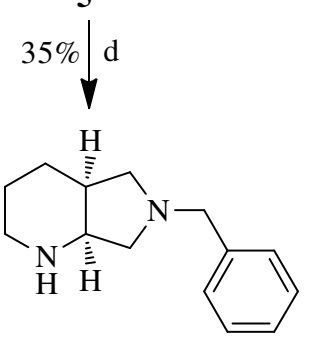

6

a) $\mathrm{Ac}_{2} \mathrm{O}$, toluene, benzylamine, water; b) $\mathrm{H}_{2}, \mathrm{Ru}-\mathrm{C}$; b) $\mathrm{LiAlH}_{4}$, THF, 0 - $5^{\circ} \mathrm{C}, 10 \mathrm{~h}$; c) DMF, IPA, ethanol, D-(-)-tartaric acid; d) Pd/C, methanol.

Scheme-I: Precedented approach for $\mathbf{1}^{1,2}$

with stirring at $0-10{ }^{\circ} \mathrm{C}$ and temperature increased to $15-20{ }^{\circ} \mathrm{C}$ for $1 \mathrm{~h}, 60 \mathrm{~mL}$ of MTBE was added and continued stirring for 30-60 min. Reaction mass was cooled to $0-5^{\circ} \mathrm{C}$ for $1 \mathrm{~h}$, filtered the precipitated material and washed with $20 \mathrm{~mL}$ of MTBE to furnish $27 \mathrm{~g}$ of dichloro compound in the form of hydrochloride salt as a white solid. This material was added to $150 \mathrm{~mL}$ of DCM with stirring, $100 \mathrm{~mL}$ of water also added and $\mathrm{pH}$ of the reaction mass was adjusted to 7.5-8.0 with $5 \%$ sodium carbonate solution. Organic layer was separated and extracted aqueous layer with $50 \mathrm{~mL}$ of DCM. Combined extracts were concentrated under reduced pressure at below $40{ }^{\circ} \mathrm{C}$ to furnish $20 \mathrm{~g}$, $(0.113 \mathrm{~mol}, 88 \%)$ of 3-bis(chloromethyl)pyridine 7 as a light brown coloured oil. IR $\left(\mathrm{KBr}, \mathrm{v}_{\max }, \mathrm{cm}^{-1}\right)$ : 3033.52 (aromatic $\mathrm{CH}), 2928.21$ (aliphatic $\mathrm{CH}$ ), 1612.04 (aromatic $\mathrm{C}=\mathrm{C}$ ); ${ }^{1} \mathrm{H}$ NMR (400 MHz, DMSO- $\left.d_{6}\right): \delta(\mathrm{ppm}) .8 .68(\mathrm{q}, 1 \mathrm{H}, J=2 \mathrm{~Hz})$, 8.23 (q, 1H, 1.6Hz), $7.68(\mathrm{q}, 1 \mathrm{H}, J=5.2 \mathrm{~Hz}), 5.05(\mathrm{~s}, 2 \mathrm{H})$, $5.01(\mathrm{~s}, 2 \mathrm{H}) ;{ }^{13} \mathrm{C}$ NMR (400 MHz, CDMSO- $\left.d_{6}\right): \delta(\mathrm{ppm})$ $153.12,147.63,140.97,133.25,125.08,42.69$, 41.54; MS (ESI): $\mathrm{m} / \mathrm{z}$ calculated for $\mathrm{C}_{7} \mathrm{H}_{7} \mathrm{Cl}_{2} \mathrm{~N}(\mathrm{M}+\mathrm{H})$ : 175.0; found: $\left(\mathrm{M}+\mathrm{H}^{+}\right)$176.0.<smiles>[14CH3][14CH2][14CH2]c1ncccc1CCl</smiles>

(S)-2-(6-Methoxynaphthalen-2-yl)propanamide (8): $100 \mathrm{~g},(0.43 \mathrm{~mol}, 1.0 \mathrm{eq})$ of (S)-naproxen 13 was dissolved in $500 \mathrm{~mL}$ of DCM and $1 \mathrm{~mL}$ of DMF with stirring and cooled to $0-5{ }^{\circ} \mathrm{C} .103 .47 \mathrm{~g},(0.86 \mathrm{~mol}, 2.0 \mathrm{eq})$ of thionyl chloride was added through addition dropper at $0-5^{\circ} \mathrm{C}$, reaction mass was heated to reflux for 6-8 h, after completion of the reaction, concentrated under reduced pressure at below $50^{\circ} \mathrm{C}$ and diluted with $500 \mathrm{~mL}$ of dichloromethane. Anhydrous ammonia was continuously added up to $\mathrm{pH}$ of the reaction mass was 10 and stirring was continued for $1 \mathrm{~h}$. Filtered precipitated material and washed with $200 \mathrm{~mL}$ of dichloromethane, this wet material was added to $200 \mathrm{~mL}$ of $2 \%$ sodium carbonate solution and continued stirring for 30-60 min stirring. Filtered the material and washed with $100 \mathrm{~mL}$ of water. Wet material dried at $60{ }^{\circ} \mathrm{C}$ to furnish $95 \mathrm{~g}(0.414 \mathrm{~mol}, 95.4 \%)$ of 2-(6-methoxynaphthalen2-yl)propanamide 8 as a off-white powder. IR $\left(\mathrm{KBr}, \mathrm{v}_{\max }, \mathrm{cm}^{-1}\right)$ : $3350.04(\mathrm{NH}), 3195.34$ (aromatic CH), 2983.51 (aliphatic $\mathrm{CH}$ ), 1606.38 (aromatic $\mathrm{C}=\mathrm{C}$ ); ${ }^{1} \mathrm{H}$ NMR $\left(400 \mathrm{MHz}, \mathrm{DMSO}-d_{6}\right): \delta$ (ppm).7.70-7.78 (m, 3H), $7.43(\mathrm{q}, 1 \mathrm{H}, J=2 \mathrm{~Hz}), 7.40(\mathrm{~s}, 1 \mathrm{H})$, 7.26 (s, 1H), $7.12(\mathrm{~d}, 1 \mathrm{H}), J=2.4 \mathrm{~Hz}), 6.83(\mathrm{~s}, 1 \mathrm{H}), 3.85$ (s, $1 \mathrm{H}), 3.70(\mathrm{q}, 1 \mathrm{H}, J=6.8 \mathrm{~Hz}), 1.37(\mathrm{~d}, 3 \mathrm{H}, J=6.8 \mathrm{~Hz}) ;{ }^{13} \mathrm{C}$ NMR (400 MHz, DMSO- $d_{6}$ ): $\delta$ (ppm) 176.47, 157.42, 137.76, $133.58,129.27,128.79,127.12$, 126.86, 125.75, 119.03, 106.12, 55.59, 45.21, 18.67; MS (ESI): $\mathrm{m} / \mathrm{z}$ calculated for $\mathrm{C}_{14} \mathrm{H}_{15} \mathrm{NO}_{2}(\mathrm{M}+\mathrm{H})$ : 229.27; found: $\left(\mathrm{M}+\mathrm{H}^{+}\right) 230.4$.<smiles>COc1ccc2cc([C@@H](C)C(N)=O)ccc2c1</smiles>

(S)-2-(6-Methoxynaphthalen-2-yl)propanamide (8)

(S)-2-(6-methoxynaphthalen-2-yl)-1-(5H-pyrrolo[3,4b]pyridin-6(7H)-yl)propan-1-one (9): A mixture of 6,7dihydro-5H-pyrrolo[3,4-b]pyridine hydrochloride 12 (20 g, $0.12 \mathrm{~mol}$ ) and dichloromethane was stirred for $10-15 \mathrm{~min}$. To this mixture diisopropylethylamine ( $82.42 \mathrm{~g}, 0.63 \mathrm{~mol}, 5.25$ eq), was added slowly through addition dropper at $10-20{ }^{\circ} \mathrm{C}$, followed by (S)-2-(6-methoxynaphthalen-2-yl)propanoyl chloride (40 g, $0.16 \mathrm{~mol}, 1.34 \mathrm{eq}$ ), in dichloromethane (500 $\mathrm{mL}$ ) was added at below $25^{\circ} \mathrm{C}$ and maintained for $2 \mathrm{~h}$ at 25 $35^{\circ} \mathrm{C}$. After completion of the reaction water $(400 \mathrm{~mL})$ was added and stirred for $15 \mathrm{~min}$. Organic layer was separated and extracted aq. layer with dichloromethane $(2 \times 200 \mathrm{~mL})$, combined organic layer was washed with $10 \%$ sodium carbonate solution. Final organic layer was dried with sodium sulphate and solvent was evaporated under reduced pressure at below $40{ }^{\circ} \mathrm{C}$ to afford $22 \mathrm{~g},(0.094 \mathrm{~mol}, 74 \%)$ of (S)-2-(6-methoxynaphthalen-2-yl)-1-(5H-pyrrolo[3,4-b]pyridin-6(7H)yl)propan-1-one 9 as a light brown coloured liquid. IR ( $\mathrm{KBr}$, 
$\mathrm{v}_{\max }, \mathrm{cm}^{-1}$ ): 3035.30 (aromatic $\mathrm{CH}$ ), 2965.07 (aliphatic $\mathrm{CH}$ ), $1606.37(\mathrm{C}=\mathrm{C}), 1163.61(\mathrm{C}-\mathrm{O})$; ${ }^{1} \mathrm{H}$ NMR (400 MHz, DMSO$\left.d_{6}\right): \delta(\mathrm{ppm}) .8 .39-8.43(\mathrm{~m}, 1 \mathrm{H}), 7.68-7.81(\mathrm{~m}, 4 \mathrm{H}), 7.46(\mathrm{~d}$, $1 \mathrm{H}, J=4 \mathrm{~Hz}), 7.23-7.27(\mathrm{~m}, 2 \mathrm{H}), 7.13(\mathrm{dd}, 1 \mathrm{H}, J=2.8 \mathrm{~Hz}$, $J=2.8 \mathrm{~Hz}), 5.10(\mathrm{t}, 1 \mathrm{H}, J=16.8 \mathrm{~Hz}), 4.41-4.77(\mathrm{~m}, 3 \mathrm{H})$, 4.15-4.20 (m, 1H), 3.84 (s, 3H), $1.42(\mathrm{~d}, 3 \mathrm{H}, J=7.2 \mathrm{~Hz}) ;{ }^{13} \mathrm{C}$ NMR (400 MHz, DMSO- $\left.d_{6}\right): \delta$ (ppm) 172.12, 157.17, 152.72, $148.86,136.40,133.17,131.39,130.30,129.09,128.47$, $127.18,126.35,125.70,122.48,118.68,105.69,55.12,52.21$, 50.31, 42.68, 20.07; HRMS (ES) calcd. (\%) for $\mathrm{C}_{21} \mathrm{H}_{21} \mathrm{~N}_{2} \mathrm{O}_{2}$ $\left(\mathrm{MH}^{+}\right) 333.1603$ and found 333.1587; SOR: [ $\alpha$ ]D25 = 67.5 (c $=0.04 \%$ in ethanol).

(S)-1-[(4aS,7aS)-Hexahydro-1H-pyrrolo[3,4-b]pyridin6(2H)-yl]-2-(6-methoxynaphthalen-2-yl)propan-1-one (10): $10 \mathrm{~g}$, (0.03 mol, $1.0 \mathrm{eq})$ of (S)-2-(6-methoxynaphthalen-2yl)-1-(5H-pyrrolo[3,4-b]pyridin-6(7H)-yl)propan-1-one 9 was added to $100 \mathrm{~mL}$ of toluene, $3 \mathrm{~g}$, of $5 \%$ palladium carbon was added in hydrogen pressure vessel. Reaction mass was warmed to $80{ }^{\circ} \mathrm{C}$ under $8 \mathrm{~kg} / \mathrm{cm}^{2}$ hydrogen pressure for $20-24 \mathrm{~h}$, after completion of the reaction was cooled to room temperature, catalyst was separated by filtration on hyflow and washed with $100 \mathrm{~mL}$ of methanol. The combined filtrates were concentrated under reduced pressure to obtain crude in the form of residue. This residue was dissolved in IPA and dry $\mathrm{HCl}$ gas was passed up to reaction mass $\mathrm{pH}$ attained to below 2 and continued stirring for additional $5 \mathrm{~h}$. Precipitated material was filtered and washed with $5 \mathrm{~mL}$ of chilled IPA. This wet material was extracted into DCM by adjusting the $\mathrm{pH}$ to 10 with $5 \%$ $\mathrm{Na}_{2} \mathrm{CO}_{3}$ solution. Volatiles were removed under reduced pressure at below $45^{\circ} \mathrm{C}$ under reduced pressure to afford $4.5 \mathrm{~g}$, $(0.013 \mathrm{~mol}, 45 \%)$ of $(\mathrm{S})-1-((4 \mathrm{aS}, 7 \mathrm{aS})$-hexahydro- $1 \mathrm{H}$ pyrrolo[3,4-b]pyridin-6(2H)-yl)-2-(6-methoxynaphthalen-2yl)propan-1-one $\mathbf{1 0}$ as a light yellow coloured liquid. IR ( $\mathrm{KBr}$, $v_{\max }, \mathrm{cm}^{-1}$ ): 3127.82 (aromatic $\mathrm{CH}$ ), 2933.73 (aliphatic $\mathrm{CH}$ ), $1635.64(\mathrm{C}=\mathrm{O}), 1504.48$ (aromatic $\mathrm{C}=\mathrm{C}), 1172.72(\mathrm{C}-\mathrm{O}) ;{ }^{1} \mathrm{H}$ NMR (400 MHz, DMSO- $\left.d_{6}\right): \delta(\mathrm{ppm}) .7 .77(\mathrm{~d}, 2 \mathrm{H}, J=8.5$ $\mathrm{Hz}), 7.70(\mathrm{~s}, 1 \mathrm{H}), 7.42$ (t, 1H, $J=7 \mathrm{~Hz}), 7.27$ (s, 1H), 7.14 (dd, $1 \mathrm{H}, J=2.5 \mathrm{~Hz}, 2 \mathrm{~Hz}), 3.89-4.00$ (m, 1H0, 3.86 (s, 3H), 3.60-3.66 (m, 1H), 3.03-3.45 (m, 7H), 2.32-2.44 9m, 1H), 1.96$2.06(\mathrm{~m}, 1 \mathrm{H}), 1.50-1.55(\mathrm{~m}, 2 \mathrm{H}), 1.35(\mathrm{~d}, 3 \mathrm{H}, J=6.5 \mathrm{~Hz}) ;{ }^{13} \mathrm{C}$ NMR (400 MHz, DMSO- $d_{6}$ ): $\delta$ (ppm) 191.92, 160.18, 138.19, $134.15,132.27,131.03,127.86,127.67,123.54,119.87$, 106.04, 55.39; HRMS (ES) calcd. (\%) for $\mathrm{C}_{21} \mathrm{H}_{27} \mathrm{~N}_{2} \mathrm{O}_{2}\left(\mathrm{MH}^{+}\right)$ 339.2073 and found 339.2056; SOR: $[\alpha] \mathrm{D} 25=122.8^{\circ}(\mathrm{c}=$ $0.01 \%$ in ethanol).

6,7-Dihydro-5 $\boldsymbol{H}$-pyrrolo[3,4-b]pyridine (12): $17 \mathrm{~g}$, (0.062 mol, 1.0 eq) of 6-(2,4-dimethoxybenzyl)-6,7-dihydro$5 H$-pyrrolo [3,4-b] pyridine was added to $15 \mathrm{~mL}$ of trifluoroacetic acid and $5 \mathrm{~mL}$ of triethyl silane with stirring at room temperature. This mixture was heated to $60-65^{\circ} \mathrm{C}$ for $4 \mathrm{~h}$, after completion of the reaction, $50 \mathrm{~mL}$ of ethyl acetate was added with stirring and cooled to room temperature, $50 \mathrm{~mL}$ of $5 \% \mathrm{HCl}$ in ethyl acetate was added slowly drop by drop at room temperature in 30-45 min and stirring was continued till material precipitation, filtered the precipitated material and washed with $25 \mathrm{~mL}$ of ethyl acetate to furnish $11 \mathrm{~g},(0.056$ mol, $90 \%$ ) of 6,7-dihydro-5H-pyrrolo[3,4-b]pyridine hydrochloride 12 as a brown solid. IR $\left(\mathrm{KBr}, \mathrm{v}_{\max }, \mathrm{cm}^{-1}\right)$ : 3431.58 (NH), 3031.97 (aromatic CH), 2971.44 (aliphatic CH), 1622.84 (aromatic $\mathrm{C}=\mathrm{C}) ;{ }^{1} \mathrm{H}$ NMR $\left(400 \mathrm{MHz}, \mathrm{DMSO}-d_{6}\right): \delta(\mathrm{ppm})$. $10.07(\mathrm{~s}, 1 \mathrm{H}), 8.52(\mathrm{~d}, 1 \mathrm{H}, J=4.4 \mathrm{~Hz}), 7.85(\mathrm{~d}, 1 \mathrm{H}, J=7.2$ $\mathrm{Hz}), 7.38(\mathrm{q}, 1 \mathrm{H}, J=4.8 \mathrm{~Hz}), 4.65(\mathrm{~s}, 2 \mathrm{H}), 4.54(\mathrm{~s}, 2 \mathrm{H}) ;{ }^{13} \mathrm{C}$ NMR (400 MHz, $\mathrm{CDCl}_{3}$ ): $\delta$ (ppm) 191.92, 160.18, 138.19, 134.15, 132.27, 131.03, 127.86, 127.67, 123.54, 119.87, 106.04, 55.39; MS (ESI): m/z calcd. $(\%)$ for $\mathrm{C}_{7} \mathrm{H}_{8} \mathrm{~N}_{2}(\mathrm{M}+\mathrm{H})$ : 120.15; found: $\left(\mathrm{M}+\mathrm{H}^{+}\right) 121.1$.

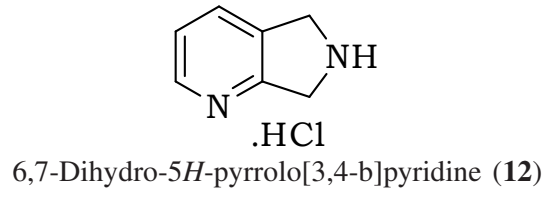

(4aS,7aS)-Octahydro-1H-pyrrolo[3,4-b]pyridine (1): $5 \mathrm{~g}(0.014 \mathrm{~mol}, 1 \mathrm{eq})$ of $(\mathrm{S})-1-((4 \mathrm{aS}, 7 \mathrm{aS})$-hexahydro- $1 H-$ pyrrolo[3,4-b]pyridin-6(2H)-yl)-2-(6-methoxy naphthalen-2yl)propan-1-one $\mathbf{1 0}$ was added into round bottom flask. To this $30 \mathrm{~mL}$ of $20 \%$ aq. methanol and $8.2 \mathrm{~g},(0.14 \mathrm{~mol}, 10 \mathrm{eq})$ of $\mathrm{KOH}$ was added with stirring at room temperature. Warmed the reaction mass to reflux for $72 \mathrm{~h}$, after completion of the reaction, methanol was evaporated under reduced pressure at below $60{ }^{\circ} \mathrm{C} .25 \mathrm{~mL}$ of water was added, extracted aqueous layer with $3 \times 25 \mathrm{~mL}$ of $\mathrm{CHCl}_{3}$; combined organic layer was dried over $\mathrm{Na}_{2} \mathrm{SO}_{4}$, clear filtrate was concentrated under reduced pressure at below $50{ }^{\circ} \mathrm{C}$ to furnish $1.8 \mathrm{~g},(0.014 \mathrm{~mol}$, $96 \%$ ) of (4aS, 7aS)-octahydro- $1 H$-pyrrolo[3,4-b]pyridine 1 as a light brown coloured liquid.

Aqueous layer was taken and adjusted the $\mathrm{pH}$ to 2 with aqueous $\mathrm{HCl}$ and extracted into toluene; isolated racemic naproxen $\mathbf{1 4}$ from toluene at $0-5{ }^{\circ} \mathrm{C}$ after charcoal treatment as half white coloured powder $(3.23 \mathrm{~g}, 95 \%$ yield with $97 \%$ purity).

(4aS,7aS)-Octahydro-1H-pyrrolo[3, 4-b]pyridine (1): Purity by HPLC: $96.7 \%$; chiral purity by HPLC: $98.93 \% ;{ }^{1} \mathrm{H}$ NMR (400 MHz, DMSO- $\left.d_{6}\right): \delta$ (ppm). 2.95-2.98 (m, 1H), 2.63-2.82 (m, 4H), $2.54(\mathrm{dd}, 1 \mathrm{H}, J=1.6 \mathrm{~Hz}, J=1.2 \mathrm{~Hz}), 2.39$ 2.45 (m, 1H), 2.16-2.45 (br, s, 2H), 1.81-1.89 (m, 1H), 1.59$1.66(\mathrm{~m}, 2 \mathrm{H}), 1.35-1.46(\mathrm{~m}, 1 \mathrm{H}), 1.24-1.31(\mathrm{~m}, 1 \mathrm{H}) ;{ }^{13} \mathrm{C} \mathrm{NMR}$ (400 MHz, DMSO- $d_{6}$ ): $\delta$ (ppm) 57.43, 53.37, 47.78, 44.49, 37.85, 23.51, 21.90; MS (ESI): $\mathrm{m} / \mathrm{z}$ calcd. $(\%)$ for $\mathrm{C}_{7} \mathrm{H}_{14} \mathrm{~N}_{2}$ $(\mathrm{M}+\mathrm{H}): 126.20$; found $(\%):\left(\mathrm{M}+\mathrm{H}^{+}\right) 126.7$; SOR: $[\alpha] \mathrm{D} 25=$ $-3.769^{\circ}(\mathrm{c}=2 \%$ in ethanol).

Racemic naproxen (14): m.p. $155-158^{\circ} \mathrm{C} ;{ }^{1} \mathrm{H}$ NMR (400 MHz, DMSO- $\left.d_{6}\right) \delta 7.66-7.68(\mathrm{~d}, 3 \mathrm{H}, J=8.8 \mathrm{~Hz}), 7.39(\mathrm{dd}$, $1 \mathrm{H}, J=1.5 \mathrm{~Hz}, J=8.3 \mathrm{~Hz}), 7.08-7.13(\mathrm{~m}, 2 \mathrm{H}), 3.8(\mathrm{~s}, 3 \mathrm{H})$, 3.82-3.86 ( m, 1H), $1.56(\mathrm{~d}, 3 \mathrm{H}, J=6.8) ;{ }^{13} \mathrm{C} \mathrm{NMR}(400 \mathrm{MHz}$, $\left.\mathrm{CDCl}_{3}\right): \delta 180.91,157.65,134.83,133.77,129.27,128.84$, 127.20, 126.16, 126.11, 119.01, 105.52, 55.27, 45.21, 18.10; MS: calcd. (\%) for $\mathrm{C}_{14} \mathrm{H}_{14} \mathrm{O}_{3} 230\left(\mathrm{M}^{+}\right)$, found $23\left(\mathrm{MH}^{+}\right)$; IR $\left(\mathrm{KBr}, v_{\max }, \mathrm{cm}^{-1}\right): 3201.02(\mathrm{OH}), 1728(\mathrm{C}=\mathrm{O}), 3002.9$ (aromatic $\mathrm{CH}), 855.66(\mathrm{C}=\mathrm{C}), 1264.69(\mathrm{CO})$; SOR: $[\alpha] \mathrm{D} 25=0.02^{\circ}(\mathrm{c}=$ $1 \%$ in chloroform).

\section{RESULTS AND DISCUSSION}

In our endeavor, we attempted to improve the enantioselectivity during the reduction of 6-benzyl-5H-pyrrolo[3,4b]pyridine-5,7(6H)-dione (3) involving the reduction of pyridine ring using L-proline as a chelating agent and $5 \%$ palladium 
TABLE-1

REDUCTION OF COMPOUND 3 IN PRESENCE OF L-PROLINE

\begin{tabular}{|c|c|c|c|c|c|c|}
\hline \multirow{2}{*}{ Entry } & \multirow{2}{*}{ Solvent } & \multirow{2}{*}{ Reducing agent } & \multirow{2}{*}{ L-Proline qty (eq) } & \multirow{2}{*}{ Yield (\%) } & \multicolumn{2}{|c|}{ *Chiral HPLC (\%) } \\
\hline & & & & & Desired & Undesired \\
\hline 1 & Toluene & $\mathrm{Pd} / \mathrm{C}$ & 0.00 & 94 & 50.5 & 49.4 \\
\hline 2 & Toluene & $\mathrm{Pd} / \mathrm{C}$ & 0.10 & 96 & 50.2 & 49.8 \\
\hline 3 & Toluene & $\mathrm{Pd} / \mathrm{C}$ & 1.2 & 96 & 57.4 & 42.6 \\
\hline 4 & Methanol & $\mathrm{Pd} / \mathrm{C}$ & 1.2 & 96 & 53.6 & 46.4 \\
\hline 5 & $\mathrm{AcOH}$ & $\mathrm{Pd} / \mathrm{C}$ & 1.2 & 90 & 54.1 & 45.9 \\
\hline 6 & Ethanol & $\mathrm{Pd} / \mathrm{C}$ & 1.2 & 92 & 53.5 & 46.5 \\
\hline 8 & Toluene & $\mathrm{Pd}-\mathrm{Cu} / \mathrm{C}$ & 1.2 & 91 & 57.5 & 42.5 \\
\hline
\end{tabular}

on carbon as reducing agent. The required amide 3 for employed in the reduction was synthesized using known procedure ${ }^{3}$. Present studies involve varying the mole ratio of L-proline by using $\mathrm{Pd} / \mathrm{C}$ and $\mathrm{Pd}-\mathrm{Cu} / \mathrm{C}$ as a reducing agents were conducted and the results are summarized in Table- 1 . When the reaction was performed with the catalytic quantity of L-proline there was no enhancement in the $e e$ and it was similar to racemic mixture (entry 2 in Table-1). Increasing the quantity of additive (L-proline) to stoichiometric amount brought about a marginal increase in $e e$ in favour of the desired isomer (entry 3 in Table-1).

In the next step, various solvents were screened to find out the impact on selectivity. It can be observed that there was no big impact on enantioselectivity with various solvents screened except toluene as shown in Table-1 (entry 3).<smiles>O=C1c2cccnc2C(=O)N1Cc1ccccc1</smiles>

3

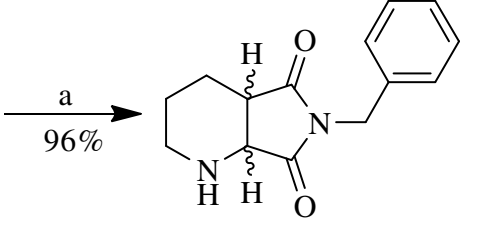

4 a) $\mathrm{Pd} / \mathrm{C}$, L-proline, toluene, $80^{\circ} \mathrm{C}, 24 \mathrm{~h}$.

Scheme-II: Reduction of $\mathbf{3}$

While the possible hydrogen bonding effect of L-proline was demonstrated to achieve the selectivity up to $15 \%$ ee further study focused on the reducing agent. Copper-palladium couple on carbon catalyst was used as a reducing agent. However selectivity could not be improved (Table-1; entry 7).

It was observed that there was no remarkable effect of solvent and additive L-proline on the selective hydrogenation of the pyridine ring. In continuation with the studies, we shifted our focus to find an alternative route that could furnish the enantiomerically pure nonane.

At first bis(chloromethyl)pyridine 7 was synthesized following the known procedure ${ }^{9}$. Our attempts to cyclize the chloro intermediate 7 by using benzamide was not successful. In addition to this, various other bases screened to couple the benzamide and chloro intermediate and attempts were unsuccessful.

In order to increase the reactivity of amide component, (S)-2-(6-methoxynaphthalen-2-yl)propanamide 8 was selected for condensation assuming that it is more reactive than the benzamide and being chiral it might help in getting selectivity during the reduction.

Substantial improvement was observed in reaction time and yield. Unprecedented reaction conditions employed for condensation involved reaction temperature of $80-90{ }^{\circ} \mathrm{C}$ using 5 mol equivalents of sodium hydride in 10 volume toluene. The results are summarized in Table- 2 .

\begin{tabular}{cccccc}
\multicolumn{7}{c}{ TABLE-2 } \\
OPTIMIZATION OF NaH QUANTITY \\
\hline Entry & Base & Solvent & Base Qty $(\mathrm{Eq})$ & Temp. $\left({ }^{\circ} \mathrm{C}\right)$ & $9(\%)$ \\
\hline 1 & $\mathrm{NaH}$ & Toluene & 3 & $80-90$ & 60 \\
2 & $\mathrm{NaH}$ & Toluene & 4 & $80-90$ & 75 \\
3 & $\mathrm{NaH}$ & Toluene & 5 & $80-90$ & 90 \\
\hline *Confirmed by TLC.
\end{tabular}

Thereafter (S)-2-(6-methoxynaphthalen-2-yl)-1-(5Hpyrrolo [3,4-b]pyridin-6(7H)-yl)propan-1-one 9 was subjected to hydrogenation with $5 \%$ palladium catalyst followed by deprotection with $\mathrm{HBr}$ in acetic acid to afford the target nonane 1 (Scheme-III). The resulted nonane was analyzed for chiral purity and it was found to be a racemic. However, the reaction time was reduced along with the improvement in the yield.

In order to understand whether the zero enantioselectivity was due to non-selective hydrogenation or early on racemization of chiral centre present in naproxen amide $\mathbf{8}$ under basic conditions or not, we performed control experiment by employing similar reaction condition i.e., NaH/toluene. Chiral HPLC analysis of the product showed the complete racemization (Scheme-IV). Results are summarized in Table-3.

\begin{tabular}{cccc}
\multicolumn{5}{c}{ TABLE-3 } \\
CHIRAL HPLC RESULTS OF 8 \\
\hline \multirow{2}{*}{ Entry } & $\begin{array}{c}\text { (S)-2-(6-Methoxynaphthalen-2- } \\
\text { yl)propanamide (8) }\end{array}$ & $\begin{array}{c}\text { S-Isomer } \\
(\%)\end{array}$ & $\begin{array}{c}\text { R-Isomer } \\
(\%)\end{array}$ \\
\hline 1 & Initial & 98 & 2 \\
2 & After 0.5 h maintenance at $80-90^{\circ} \mathrm{C}$ & 55 & 45 \\
\hline
\end{tabular}

Since the reaction conditions employed for di-alkylation was leading to racemization of the (S)-2-(6-methoxynaphthalen2-yl)propanamide $\mathbf{8}$, we adopted another approach featuring the preparation of 6,7-dihydro-5 $H$-pyrrolo[3,4-b]pyridine 12 following the known procedure ${ }^{10}$. Alkylation of the 6,7-dihydro5H-pyrrolo[3,4-b]pyridine 12 with (S)-naproxen 13 was carried out in presence of phenyl boronic acid as catalyst in $o$-xylene at $145^{\circ} \mathrm{C}$. The intermediate obtained after 2-(6-methoxynaphthalen-2-yl)-1-(5H-pyrrolo[3,4-b]pyridin-6(7H)-yl)propan- 
<smiles>CCc1cccnc1CCl</smiles>

7<smiles>CCc1ccc2c(c1)CN(C(=O)[C@H](C)c1ccc3cc(OC)ccc3c1)C2</smiles>

9<smiles>COc1ccc2cc([C@@H](C)C(=O)N3CC4CCCNC4C3)ccc2c1</smiles>

$10 \mathbf{a}$

a) (S)-Naproxamide (8), toluene, $\mathrm{NaH}, 80-90^{\circ} \mathrm{C}, 5 \mathrm{~h}, \mathrm{AcOH}, \mathrm{EA}, \mathrm{H}_{2} \mathrm{O}$, n-heptane; b) $5 \% \mathrm{Pd} / \mathrm{C}$, toluene, $80{ }^{\circ} \mathrm{C}, 8 \mathrm{~kg} / \mathrm{cm}^{2}, 24 \mathrm{~h}$; c) $48 \% \mathrm{HBr}$, propionic acid,phenol, reflux, 6 - 7h, MTBE, EA, $\mathrm{NaOH}, \mathrm{H} 2 \mathrm{O}, \mathrm{NaCl}, \mathrm{CHCl}_{3}$.

Scheme-III: Novel approach for $\mathbf{1}$<smiles>COc1ccc2cc([C@H](C)C(N)=O)ccc2c1</smiles>

a) $\mathrm{NaH}$, toluene, $85-90^{\circ} \mathrm{C}, 30$ minutes.

Scheme-IV: Racemization of $\mathbf{8}$

1-one 9 was subjected to reduction of pyridine ring using $5 \%$ palladium on carbon catalyst in toluene to afford the 1-(hexahydro$1 H$-pyrrolo [3, 4-b] pyridin-6(2H)-yl)-2-(6-methoxynaphthalen2-yl) propan-1-one 10, which was subjected to de-coupling to yield the target intermediate nonane $\mathbf{1}$ (Scheme-V).

To our surprise, we once again encountered with racemization. The reason for ending up with racemic compound was found to be due to racemization of the (S)-naproxen 13 during the coupling with 6,7-dihydro-5H-pyrrolo[3,4-b] pyridine $\mathbf{1 2}$. This was confirmed by chiral HPLC analysis of (S)-naproxen 13 before and after reflux in $o$-xylene in presence of phenyl boronic acid as a catalyst and in absence of intermediate 12, respectively. Chiral HPLC results are summarized in Table-4 (Scheme-VI).

\begin{tabular}{cccc}
\multicolumn{5}{c}{ TABLE-4 } \\
CHIRAL HPLC RESULTS OF 13 \\
\hline \multirow{2}{*}{ Entry } & (S)-Naproxen (13) & S-Isomer & R-Isomer \\
& & $(\%)$ & $(\%)$ \\
\hline 1 & Initial & 99.8 & 0.2 \\
2 & After $10 \mathrm{~h}$, maintenance at $145^{\circ} \mathrm{C}$ & 51.5 & 48.5 \\
\hline
\end{tabular}

Hence, we concluded that the racemization of the coupling agent was not only due to presence of strong base, but also due to the reaction temperature in the presence of acidic catalyst.

Keeping in view of the extreme reaction conditions leading to racemization of the coupling agent, the coupling agent was primarily activated by making its acid chloride and then coupled with the 6,7-dihydro-5 $H$-pyrrolo[3,4-b]pyridine $\mathbf{1 2}$ using DIPEA as a $\mathrm{HCl}$ scavenger at $0-5^{\circ} \mathrm{C}$. The coupled intermediate 9 was further reduced with $5 \%$ palladium on carbon to get the reduced intermediate $\mathbf{1 0}$ followed by de-coupling with $\mathrm{HBr}$ to afford the target intermediate nonane 1 . The obtained nonane was analyzed for chiral purity and the enantioselectivity was found to be much improved $(20 \% e e)$ but still it is extremely poor proposition from synthesis standpoint (Scheme-VII).

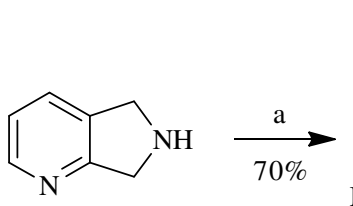

12<smiles>COc1ccc2cc([C@@H](C)C(=O)N3Cc4cccnc4C3)ccc2c1</smiles>

9<smiles>COc1ccc2cc([C@@H](C)C(=O)N3C[C@H]4CCCN[C@H]4C3)ccc2c1</smiles><smiles>[134I]</smiles><smiles>C1CNC2CNCC2C1</smiles>

1

a) (S)-Naproxene (13), o-xylene, phenylboronic acid, $\mathrm{Na}_{2} \mathrm{CO}_{3}, \mathrm{H}_{2} \mathrm{O}$, reflux, $24 \mathrm{~h}$; b) $5 \% \mathrm{Pd} / \mathrm{C}$, toluene, $80^{\circ} \mathrm{C}, 8 \mathrm{~kg} / \mathrm{cm}^{2}, 24 \mathrm{~h}$; c) $\mathrm{HBr}$ in $\mathrm{AcOH}$, phenol, propionic acid, reflux, $6-7 \mathrm{~h}, \mathrm{NaCl}, \mathrm{NaOH}, \mathrm{CHCl}_{3}$.

Scheme-V: Modified novel approach for $\mathbf{1}$ 
<smiles>COc1ccc2cc([C@@H](C)C(=O)O)ccc2c1</smiles>

13

a) o-xylene, phenyl boronic acid, ref lux, 10h.

Scheme-VI: Racemization of $\mathbf{1 3}$

Having gained intellectual control over reaction sequence, we decided to develop a simple method for purification and hydrolysis of $\mathbf{1 0}$ to obtain the nonane $\mathbf{1}$ and naproxen $\mathbf{1 3}$. At first the required isomer was isolated by making the $\mathrm{HCl}$ salt in IPA thereafter various bases were screened to hydrolyze 10. Among all the bases $\mathrm{KOH}$ and $\mathrm{K}^{\mathrm{t}} \mathrm{OBU}$ were afforded the best results (Table-5, entry-1 and 2).

Based on the results and observations from the experiments conducted to attain enantioselectivity of nonane, the following process was finalized. The cyclic amine intermediate ${ }^{10} \mathbf{1 2}$ was coupled with the acid chloride of (S)-naproxen $\mathbf{1 3}$ in presence of DIPEA at $0-5^{\circ} \mathrm{C}$. The crude material obtained after

\begin{tabular}{ccccc}
\hline \multicolumn{5}{c}{ TABLE-5 } \\
\hline \multicolumn{5}{c}{ SCREENING OF BASES } \\
\hline Entry & Base & Temp. $\left({ }^{\circ} \mathrm{C}\right)$ & $\%$ of 1 & $\%$ of 32 \\
\hline 1 & $\mathrm{KOH}$ & 80 & 92 & 96 \\
2 & $\mathrm{~K}^{t} \mathrm{OBU}$ & 80 & 90 & 97 \\
3 & $\mathrm{LiOH}$ & 80 & Reaction incomplete \\
4 & $\mathrm{NaOMe}$ & 80 & Reaction incomplete \\
5 & $\mathrm{NaOC}_{2} \mathrm{H}_{5}$ & 80 & Reaction incomplete \\
\hline * Reactions carried out in aq. methanol.
\end{tabular}

workup was purified through column chromatography to afford the coupled intermediate $\mathbf{9}$. The pyridine ring of the intermediate 9 was reduced using palladium on carbon as catalyst in toluene solvent. The catalyst was filtered off and the target diastereomeric intermediate was obtained as a crude. Diasteriomers were separated by making the hydrochloride salt in isopropyl alcohol. After separation, intermediate $\mathbf{1 0}$ converted to nonane by hydrolyzing with $\mathrm{KOH}$ in aqueous methanol to afford nonane $\mathbf{1}$ and racemic naproxen $\mathbf{1 4}$ with an excellent yield (95 and $90 \%$ ) was recovered (SchemeVIII).

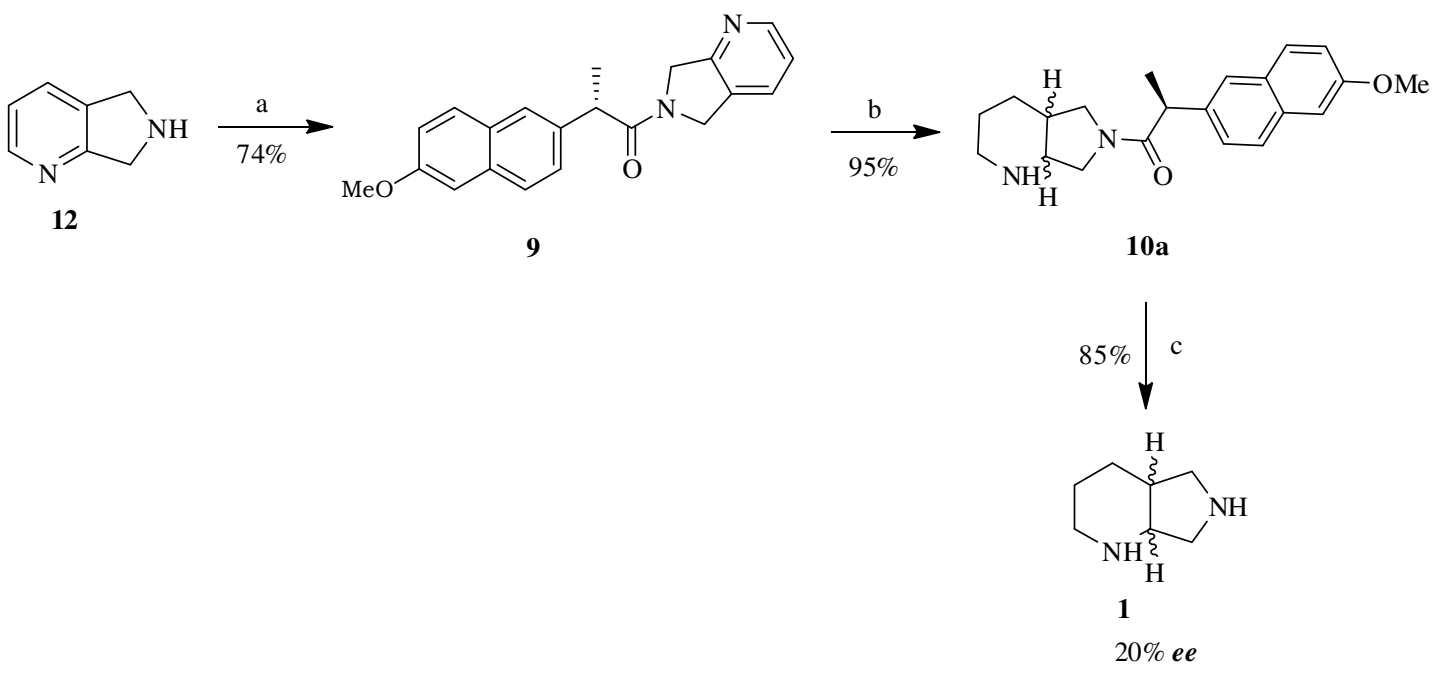

a) (S)-Naproxenacidchloride, toluene, DIEPA, $\mathrm{Na}_{2} \mathrm{CO}_{3}, \mathrm{H}_{2} \mathrm{O}, 0-5^{\circ} \mathrm{C}, 2 \mathrm{~h}$; b) $5 \% \mathrm{Pd} / \mathrm{C}$, toluene, $80^{\circ} \mathrm{C}, 8 \mathrm{~kg} / \mathrm{cm}^{2}, 24 \mathrm{~h}$; c) $\mathrm{HBr}$ in $\mathrm{AcOH}$, phenol, propionic acid, reflux, $6-7 \mathrm{~h}, \mathrm{NaCl}, \mathrm{NaOH}, \mathrm{CHCl}_{3}$.

Scheme-VII: Modified novel approach for 1

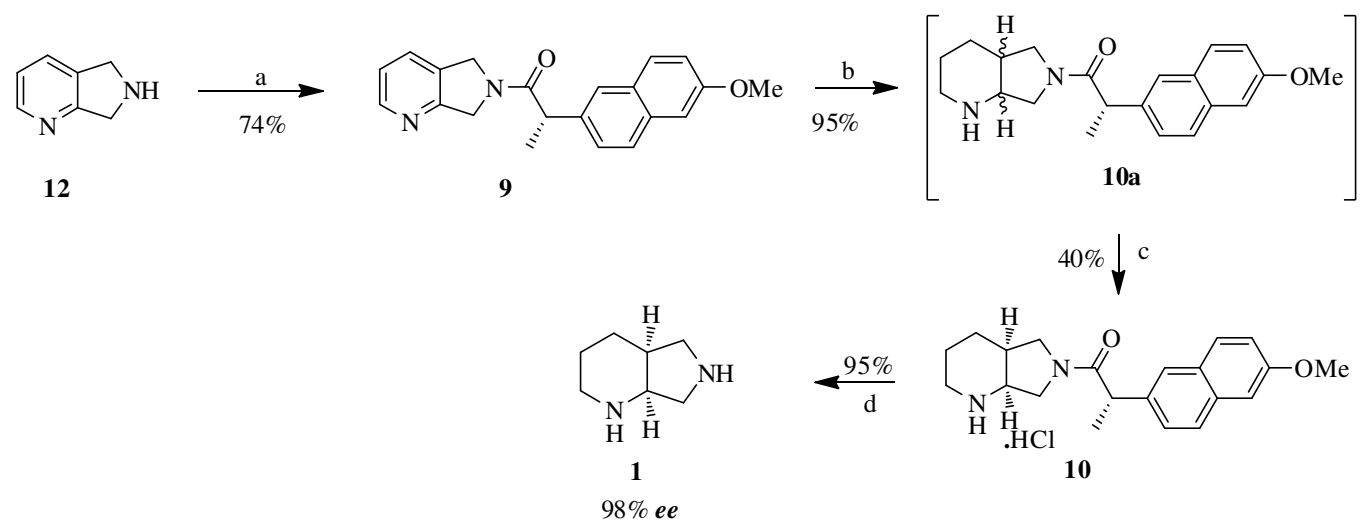

a) (S)-Naproxenacidchloride, DIEPA, $\mathrm{MDC}, \mathrm{Na}_{2} \mathrm{CO}_{3}, \mathrm{H}_{2} \mathrm{O}, 0-5^{\circ} \mathrm{C}, 1 \mathrm{~h}$; b) $5 \% \mathrm{Pd} / \mathrm{C}$, toluene, $80^{\circ} \mathrm{C}, 8 \mathrm{~kg} / \mathrm{cm}^{2}, 24 \mathrm{~h} ;$ c) IPA, dry $\mathrm{HCl}$; d) $\mathrm{KOH}$, Aq.methanol, reflux, $72 \mathrm{~h}, \mathrm{NaCl}, \mathrm{CHCl}_{3}$, Aq. $\mathrm{HCl}$, toluene. 


\section{Conclusion}

An efficient process for pyridine ring reduction with 15$20 \%$ ee has been developed by using L-proline or naproxene as a chiral auxiliary. Enantiomerically enriched novel process has been developed for $(4 \mathrm{aS}, 7 \mathrm{aS})$-octahydro- $1 \mathrm{H}$-pyrrolo[3,4b]pyridine by investigating three different approaches. We demonstrated coupling between 2,3-bis(chloromethyl)pyridine 7 and (S)-2-(6-methoxynaphthalen-2-yl)propanamide 8 for the first time in presence of sodium hydride in toluene with $70 \%$ of yield and recovery process for racemic naproxen 14 by hydrolyzing of $\mathbf{1 0}$ with $\mathrm{KOH}$ in aq. methanol was also established.

\section{ACKNOWLEDGEMENTS}

The authors thank the Management of R\&D-CTO and IPDO, Dr. Reddy's Laboratories Ltd., for supporting this work. Cooperation from the colleagues from Analytical Development is highly appreciated.

\section{REFERENCES}

1. U. Petersen, T. Schenke, A. Krebs, K. Grohe, M. Schriewer, I. Haller K. Metzger, R. Endermann and H. Zeiler, EP 0,350,733 (1990).
2. U. Petersen, A. Krebs, T. Schenke, T. Philipps, K. Grohe, K.D. Bremm, R. Endermann, K.G. Metzger and I. Haller, EP0, 550, 903 (1992).

3. A. Ramakrishnan and S.B. Narayan, V. WO 125,425 (2009).

4. J.W. Kim, H.T. Park, H.M. Kim, J.B. Kim and D.N. Pearson, US Patent 5,770,597 (1998).

5. (a) W. Zheqing, F. Shushan and C. Yongzhi, WO085480 (2008); (b) Z. Wang, S. Feng and Y. Cheng, US Patent 0,221,329 (2008).

6. W. Tianjun, Faming Zhuanli Shenqing, 7 (2010).

7. O. Masatoshi and N. Akira, WO 122,774 (2010).

8. (a) F. Peter, WO58, 532, 1999; (b) D. Claus, Ger.Offen. WO 09, 200, 1999; (c) F. Peter, US Patent 6, 235, 908 (2001); (d) D. Herbert, K. Andreas, L. Walter, P. Hanns-Ingolf, S. Dietrich, G. Rolf and R. Tobias, US Patent 0,044,205 (2004); (e) L. Mingliang, W. Yonggang, S. Lanying and G. Huiyuan, Zhongguo Yiyao Gongye Zazhi, 35, 129 (2004); (f) P. Xianhua, T. He, O. Wenhua, R. Libo and Y. Wenqiu, Faming Zhuanli Shenqing, 13 (2009); (g) M. Riccardo, A. Glancarlo, B. Elisabetta, C. Andrea, F. Stefano and G. Marco, WO100,215 (2010).

9. J.S. Grimm, C.A. Maryanoff, M. Patel, D.C. Palmer, K.L. Sorgi, S. Stefanick, R.R.H. Webster and X. Zhang, Org. Process Res. Dev., 6, 938 (2002).

10. M.S. Sakya, D.V.M. Berg, K. Pouwer, M.J. Humphrey, J.C. Helal and J.C. O’Donnel, Tetrahedron Lett., 51, 5859 (2010). 